\title{
Two novel antimicrobial and anticancer peptides prediction from Vibrio sp. strain ES25
}

\author{
Andis Sugrani ${ }^{*}$, Ahyar Ahmad ${ }^{2}$, Muhammad Natsir Djide ${ }^{3}$, Hasnah Natsir ${ }^{2}$ \\ ${ }^{1}$ Department of Medical Laboratory Technology, Megarezky University of Makassar, Makassar, Indonesia. \\ ${ }^{2}$ Chemistry Department, Mathematic and Natural Science Faculty, Hasanuddin University, Makassar, Indonesia. \\ ${ }^{3}$ Faculty of Pharmacy, Hasanuddin University, Makassar, Indonesia.
}

\begin{tabular}{l}
\hline ARTICLE INFO \\
\hline Received on: 08/03/2020 \\
Accepted on: $27 / 05 / 2020$ \\
Available online: 05/08/2020 \\
\\
\hline Key words: \\
Antibacterial, anticancer, \\
endophytic bacteria, peptide, \\
protein, protein hydrolysate, \\
Vibrio.
\end{tabular}

\section{INTRODUCTION}

Bioactive peptides are a versatile raw material for producing pharmaceutical drugs. This is due to their specific and interactive nature. Low-molecular weight peptides in particular have been shown to have strong bioactivity (Wang and Zhang, 2016). These bioactive peptides are produced from proteins by breaking the peptide bonds to produce simple chain amino acids (Kadam et al., 2015).

Peptides found endophytically within microbial hosts have been shown to be bioactive. For example, in the endophytic fungus, Aspergillus awamory found in Acacia nilotica produces antidiabetic peptides (Singh and Kaur, 2016). Unguisin F, a novel cyclic peptide, has been isolated from Mucor irregularis that is hosted in Moringa stenopetala, and has antibacterial

${ }^{*}$ Corresponding Author

Andis Sugrani, Department of Medical Laboratory Technology, Megarezky University of Makassar, Makassar, Indonesia.

E-mail: sugraniandis@gmail.com and antifungal properties (Akone et al., 2016). An endophytic bacteria isolated from red pepper leaf has also been found to produce antimicrobial and antiangiogenic peptides (Jung et al., 2015).

A crude protein extract from the endophytic Vibrio $s p$. bacterial strain ES25, isolated from Eucheuma spinosum, was previously proved to be intermediately active as an antibacterial and anticancer agent (Sugrani et al., 2019b). However, the bioactivity of a protein can be increased by the hydrolysis of proteins into peptides (Wang and Zhang, 2016). In this study, authors have first sought to provide better taxonomic information on the ES25 isolate that was previously identified through morphology by using DNA sequencing. The authors have then hydrolyzed the crude protein extract into peptides and tested its antagonistic activity against pathogenic bacteria and HeLa cell lines as well as predict functionality in silico. Finally, we present two novel peptides: QA1d-4 and QA1d-8 identified using Liquid Chromatography-Mass Spectroscopy/ Mass Spectroscopy (LC-MS/MS). These peptides are promising candidates. 


\section{MATERIALS AND METHODS}

\section{Strain and growth conditions}

The bacterial strain ES25 was previously reported to originate from the genus Vibrio and was isolated from E. spinosum from Takalar, South Sulawesi, Indonesia (Sugrani et al., 2019b). It was grown for 48 hours on a heated orbital shaker in a nutrient broth (NB, Oxoid) at $37^{\circ} \mathrm{C}$ and $150 \mathrm{rpm}$. The antibacterial activity of the isolate was tested against Staphylococcus aureus and Eschericia coli (collected from Hasanuddin University Medical Research center, Makassar, Indonesia).

\section{Identification of bacteria}

Isolated strains were identified by the rRNA sequencing. DNA was isolated using a Cetyl trimethylammonium bromide (CTAB) method (Kakade and Chaphalkar, 2017). RNA template amplification using universal primary numbers 63F (5'-CAGGCCTAACACATGCAAGTC-3') and 1387R (5'-GGGCGGAWGTGTACAAGGC-3') (Hailu et al., 2015). DNA amplification was carried out in a $\mathrm{T} 100^{\mathrm{TM}}$ BioRad thermocycler machine provided applied biosystems with conditions: $95^{\circ} \mathrm{C}(15$ minutes); 40 cycles of $94^{\circ} \mathrm{C}$ ( 60 seconds), $55.0^{\circ} \mathrm{C}$ (30 seconds), $72.0^{\circ} \mathrm{C}$ (60 seconds), final extension $72^{\circ} \mathrm{C}$ ( 5 minutes). The product was examined by $1 \%$ agarose gel stained with ethidium bromide. The gel was eluted by the SIGMA gel elution kit. The bacterial sequence was identified using the Basic Local Alignment Search Tool (BLAST) algorithm on NCBI GenBank. Phylogenetic trees were built by the Neighbor-Joining method using Clustal Omega online.

\section{Isolation of proteins from bacteria}

Fifty grams of the bacterial culture added to $500 \mathrm{ml}$ of $\mathrm{HCl}$ tris buffer and was stirred with an electric stirrer for 24 hours at $5^{\circ} \mathrm{C}$. The bacterial cells were ultrasonicated (BANDELIN Sonopuls, frequency $20 \mathrm{~Hz}, 60 \%$ amplitude, for 5 minutes) and then freeze-thawed 2-3 times, $500 \mathrm{ml}$ mixture was centrifuged at a speed of 3,200 rpm for 10 minutes. After that, the supernatant was fractionated using ammonium sulfate $\left(\mathrm{NH}_{4}\right)_{2} \mathrm{SO}_{4}$. The dissolved protein at each fractionation was extracted and then pelletized through centrifugation at $13,000 \mathrm{rpm}$ for 10 minutes at $4^{\circ} \mathrm{C}$. The protein obtained was dialyzed for 12 hours at a temperature that remained cool at $25^{\circ} \mathrm{C}-35^{\circ} \mathrm{C}$. The protein concentration in the extract was then measured using Lowry method, $4 \mathrm{ml}$ sample added with Lowry B [mixture of $100 \mathrm{ml}$ sodium carbonat $\left(\mathrm{Na}_{2} \mathrm{CO}_{3} 2 \%\right.$ dalam $0.1 \mathrm{M} \mathrm{NaOH}), 1 \mathrm{ml}$ potassium sodium tartate $\left(\mathrm{KNaC}_{4} \mathrm{H}_{4} \mathrm{O}_{6} 2 \%\right)$, and $1 \mathrm{ml}$ copper sulfate pentahydrate $\left.\left(\mathrm{CuSO}_{4} .5 \mathrm{H}_{2} \mathrm{O} 1 \%\right)\right]$; shaken and allowed to stand at room temperature for 30 minutes; then added 0.5 ml Lowry A [Folin-Ciocalteu dalam $\mathrm{H}_{2} \mathrm{O}(1: 1 \mathrm{v} / \mathrm{v})$ ]; allowed to stand again at room temperature for 30 minutes. The absorbance was read at $650 \mathrm{~nm}$, Bovine Serum Albumin as a standard (0.02, 0.04, 0.06, $0.08,0.10$, and $0.12 \mathrm{mg} / \mathrm{ml}$ ) (Maehre et al., 2018)

\section{Hydrolysis of protein}

The protein fraction was diluted into a $3 \%$ buffer solution and was hydrolyzed using pepsin (EC 3.4.23.1) using a $6 \% \mathrm{w} / \mathrm{w}$ enzyme to substrate ratio (E/S) at $37^{\circ} \mathrm{C}, \mathrm{pH} 2$ for 2 hours.
The reaction was stopped by heating the mixture to the boiling point of water for 10 minutes. The hydrolysate was then cooled and centrifuged at $10,000 \mathrm{rpm}$ and $4^{\circ} \mathrm{C}$ for 20 minutes. Finally, the hydrolysate was lyophilized before storage (Wang and Zhang, 2016). A 27.15\% degree of hydrolysis was found to have occurred.

\section{Ultrafiltration}

The lyophilized hydrolysate was ultrafiltrated by separation membrane molecular-weight-cut-off using a Vivaspin 20 Fisher Scientific. Fractions were collected in the range of: $<3$ $\mathrm{kDa}, 3-5 \mathrm{kDa}, 5-10 \mathrm{kDa}$, and $>10 \mathrm{kDa}$ and stored at $-20^{\circ} \mathrm{C}$ (Guo et al., 2015). These fractions were named as QA1d, QA1c, QA1b, and QA1a, respectively.

\section{Sodium dodecyl sulfate-polyacrylamide gel electrophoresis (SDS-PAGE)}

The molecular weight of the collected peptides was determined by SDS-PAGE using a 2-250 kDa marker and a Dual Xtra 161-0377 Bio-Rad. The $3 \mathrm{mg} / \mathrm{ml}$ of the peptide and the markers were dissolved in the sample buffer and transferred to the gel for electrophoresis (height $8 \mathrm{~cm}$, width $10 \mathrm{~cm}$, and thickness $0.6 \mathrm{~mm}$ ). Electrophoresis was conducted at $60 \mathrm{~mA}$ for 3-4 hours (Naimah et al., 2018).

\section{Toxicological assay}

Toxicological thresholds were determined using a brine shrimp lethality assay (Sugrani et al., 2019b). Artemia salina eggs were hatched using seawater for 48 hours. The protein compounds were then prepared in concentrations of $1,10,100 \mathrm{ppm}$ in $5 \mathrm{ml}$ seawater. Ten shrimp larvae were put into a bottle, but before the bottle has been filled with seawater. After 24 hours, the live larvae were counted. Seawater was used as a negative control and Dimethyl sulfoxide (DMSO) as a positive control. Probit analysis was then used to obtain $\mathrm{LC}_{50}$ values.

\section{Antibacterial assay}

The antibacterial activity of the collected proteins and peptides were tested using an agar diffusion method (Sugrani et al., 2019a) on the bacteria $S$. aureus and E. coli. Medium Muller Hinton Agar was sterilized using an autoclave set to $121^{\circ} \mathrm{C}$ a pressure of $15 \mathrm{psi}$. The $15 \mathrm{ml}$ of media was poured aseptically into a petri dish and then inoculated $200 \mu$ of bacterial suspension. Paper discs (about $6 \mathrm{~mm}$ in diameter), containing of the peptides or proteins applied as a $20 \mathrm{ul}$ were then placed on the surface of the agar and incubated for 24 hours at $37^{\circ} \mathrm{C}$ before measuring the inhibition zone.

\section{Antiproliferation assay}

$100 \mu \mathrm{l}$ of HeLa cancer cells at a density of 106 cells per well were placed into 96 wells. The cell suspension was incubated in an incubator at $37^{\circ} \mathrm{C}$ for 24 hours. $20 \mu \mathrm{l}$ peptides (concentration series were 200, 100, 50, 25, 12.5, 6.25, 3.13, and $1.56 \mu \mathrm{g} / \mathrm{ml})$ was added to the wells. After 24 hours incubation, $20 \mu \mathrm{l}$ of 3-(4,5-Dimethylthiazol-2-yl)-2,5-diphenyltetrazolium bromide (MTT) solution was added in each well and further incubated for 4 hours at $37^{\circ} \mathrm{C}, 5 \% \mathrm{CO}_{2}$. The resulting formazan 
precipitate was dissolved by adding $100 \mu \mathrm{LMSO}$ and incubated again at $37^{\circ} \mathrm{C}$ for 5 minutes. Absorbance was measured at $540 \mathrm{~nm}$ by a microplate reader to calculate cell viability. Medium without peptide and mixed with cisplatin as negative and positive control (Chu et al., 2015).

\section{Mass spectrometry (MS) and de novo sequencing}

LC and MS/MS analyses were performed using a UPLCMS [ACQUITY UPLC®H-Class System (Waters, Milford, MA)] with a binary pump. In this system, the liquid chromatography is associated with a Quadrupole Time of Flight (QTOF) mass spectrometer with an Electrospray ionization (ESI) ionization source. Mass spectroscopy was performed with a Xevo G2-X2 QTof using the positive ionization mode. The ESI parameters used were full scan mode from $\mathrm{m} / \mathrm{z} 50-3,000 \mathrm{Da}$, a column temperature of $50^{\circ} \mathrm{C}$, and room temperature $25^{\circ} \mathrm{C}$. A UPLC CORTECS C8 Column $(2.7 \mu \mathrm{m}, 2.1 \mathrm{~mm} \times 100 \mathrm{~mm})$ was used. Bioactive peptides from protein hydrolysates were identified by their amino acid sequences based on $\mathrm{m} / \mathrm{z}$ spectrum values by the de novo sequencing, using the MASCOT Program (Wang and Zhang, 2016).

\section{In silico prediction}

Anticancer activity was predicted by the using ANTICP (https://webs.iiitd.edu.in/raghava/anticp/) (Tyagi et al., 2013). CAMPR3 (http://www.camp.bicnirrh.res.in/predict/) was used for antibacterial prediction (Waghu et al., 2016). ProtParam was used to calculate various physical and chemical parameters of the isolated peptides (http://web.expasy.org/protparam) (Gasteiger et al., 2005).

\section{RESULTS AND DISCUSSION}

Based on the BLAST analysis of the 16S rRNA sequence (Table 1), ES25 was 97\% similar to Vibrio algivorus strain SA2 (GenBank ID: NR_151933.1), and therefore is unlikely to be a new species (Mansfield et al., 2015). The further assessment of the taxonomic position of the isolate using a phylogenetic tree confirmed a close relationship to. Vibrio algivorus strain SA2 (Fig. 1). The fact that ES25 sits on a new branch may indicate a novel linage to those previously identified.

The four protein hydrolysates were tested for their inhibitory activity against bacteria (E. coli and $S$. aureus). The results showed that QA1c and QA1d had a strong activity against $S$. aureus, whereas for $E$. coli, all four hydrolysates had a weak activity (Table 2). In addition, QA1d was found to be very toxic to Artemia salina (Table 3). Based on these antibacterial and toxicology results, QA1c and QA1d continued at the next stage. SDS-PAGE electrophoresis results showed that both QA1c and QA1d had a low-molecular weight (Fig. 2).

Based on the relationship of peptide concentrations with $\%$ viability of HeLa cells (Figs. 3 and 4), only QA1d peptides can contribute to HeLa cell inhibition but QA1c peptides can't. According $\mathrm{IC}_{50}$ to concentration values published by Weerapreeyakul et al. (2012), the $\mathrm{IC}_{50}$ value for QA1d $(248.18 \mu \mathrm{g} /$ $\mathrm{ml})$ and $(>4,491.88 \mu \mathrm{g} / \mathrm{ml})$ would place them in the moderate and not cytotoxic categories, respectively.

QA1d amino acid composition was identified using LCMS/MS analysis and de novo sequencing. The results of the liquid chromatography analysis showed nine peaks (Fig. 5) indicating nine separate peptides in the QA1d protein hydrolysate (Stan et al., 2016). Each chromatography peak was further analyzed by MS/ MS using Masslynx V4 (Fig. 6). Results from de novo sequencing using the MASCOT program can be seen in Table 4. One peptide was excluded from further analysis as it scored less than 60 (Wang and Zhang, 2016).

The eight peptides were further analyzed using in silico antibacterial analysis using CAMPR3 (http://www.camp.bicnirrh. res.in/predict/) and anticancer using AntiCP (https://webs.iiitd.edu. in/raghava/anticp) (Table 5). Although, in vivo and in vitro assays have been used elsewhere, these are both financially and time costly and require more sampling. Conversely, in silico analysis, can reduce costs, speed up quantification time and minimize the use of test samples (Sucher, 2014).

Table 1. 16S rRNA sequence of endophytic bacterial strain ES25.

\begin{tabular}{ll}
\hline Species & 16S rRNA sequence \\
\hline Vibrio $s p$. & GATGGAGGGAGTTTCGGATTCTGGGCGTAAGCGCATGCAGGTGGTTTGTTAAGTCAGATG \\
Strain ES25 & TGAAGCCCGGGGTCAACCTCGGAATAGCATTTGAAACTGGCAGACTAGAGTACTGTAG \\
& AGGGGGGTAGAATTTCAGGTGTAGCGGTGAAATGCGTAGAGATCTGAAGGAATACCGGTG \\
& GCGAAGGCGGCCCCCTGGACAGATACTGACACTCAGATGCGAAAGCGTGGGGAGCAAACA \\
& GGATTAGATACCCTGGTAGTCCACGCCGTAAACGATGTCTACTTGGAGGTTGTGGCCTTG \\
& AGCCGTGGCTTTCGGAGCTAACGCGTTAAGTAGACCGCCTGGGGAGTACGGTCGCAAGAT \\
& TAAAACTCAAATGAATTGACGGGGGCCCGCACAAGCGGTGGAGCATGTGGTTTAATTCGA \\
& TGCAACGCGAAGAACCTTACCTACTCTTGACATCCAGAGAACTTACCAGAGATGCATTGG \\
& TGCCTTCGGGAACTCTGAGACAGGTGCTGCATGGCTGTCGTCAGCTCGTGTTGTGAAATG \\
& TTGGGTTAAGTCCCGCAACGAGCGCAACCCTTATCCTTGTTTGCCAGCGAGTAATGTCGG \\
& AAACTCCAGGGAGACTGCCGGTGATAAAACGGAGGAAGGGGGGGACGACACAAGTCGTCA \\
& TGGGCCCGTACCAAT \\
\hline
\end{tabular}




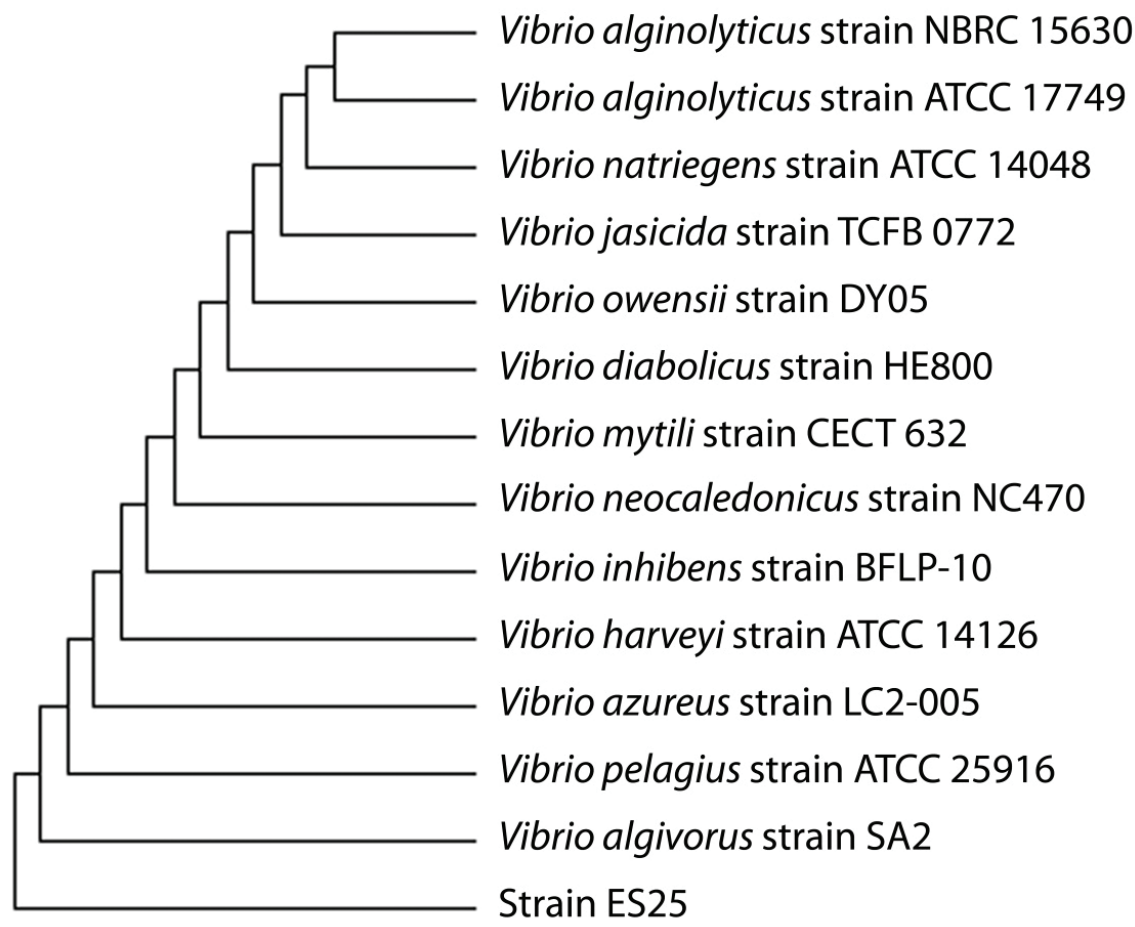

Figure 1. Phylogenetic tree of strain ES25. The phylogenetic tree was constructed by the neighbor-joining (NJ) method.

Table 2. Antibacterial activity of peptides against $S$. aureus and E. coli.

\begin{tabular}{lclcl}
\hline \multirow{2}{*}{ Fraction $^{\mathrm{a}}$} & \multicolumn{4}{c}{ Inhibition area $(\mathbf{m m})^{\mathbf{b}}$} \\
\cline { 2 - 5 } & S. aureus & Category & E. coli & Category \\
\hline QA1a & $1.70 \pm 0.57$ & Weak & $1.40 \pm 0.14$ & Weak \\
QA1b & $3.25 \pm 0.07$ & Weak & $1.35 \pm 0.07$ & Weak \\
QA1c & $10.95 \pm 0.35$ & Strong & $2.00 \pm 0.28$ & Weak \\
QA1d & $13.26 \pm 0.65$ & Strong & $3.10 \pm 0.57$ & Weak \\
K(+) & $18.40 \pm 2.40$ & Strong & $9.30 \pm 5.66$ & Moderate \\
K(-) & 0.00 & Not active & 0.00 & Not active \\
\hline
\end{tabular}

aFraction: QA1a: >10 kDa; QA1b: 5-10 kDa; QA1c: 3-5 kDa; QA1d: <3 kDa; K(+) Positive control; K(-): Negative control.

${ }^{\mathrm{b}}$ Average of two measurements.

Based on the in silico analysis, there are two peptides have the potential to be responsible for the antibacterial and anticancer activity of QA1d, QA1d-4 (HAILRGLLCLSLTLAFQPAF), and QA1d-8 (ALHLPLKLMLRPALPLRLKLTL). The exact mechanism of antibacterial and anticancer peptides is not identified in this study and would require further work (Cullen et al., 2015; Tyagi et al., 2015). There are several potential mechanisms that could be responsible for the activities observed, including the barrel-stave model, the toroidal model, and the carpet model (Li et al., 2018; Wang et al., 2017). This model mechanism occurs due to electrostatic interactions between cationic peptides (positively charged) with anionic components (negatively charged) from the cancer cell membranes (such as phosphatidylserine) or Grampositive bacteria (such as peptidoglycan). In general, an interactive relationship peptide and membrane molecules requires direct
Table 3. $\mathrm{LC}_{50}$ values of protein hydrolysate

\begin{tabular}{lcl}
\hline Fraction $^{\mathrm{a}}$ & $\mathbf{L C}_{\mathbf{5 0}}(\mathbf{\mu g} / \mathbf{m l})$ & Toxicity level \\
\hline QA1a & $>1,000$ & Not toxic \\
QA1b & 320.01 & Moderate \\
QA1c & 4.93 & Very toxic \\
QA1d & 1.03 & Very toxic \\
\hline
\end{tabular}

${ }^{\mathrm{a}}$ Fraction: Q = Crude extract; QA = Protein 20\%; QA1 = Protein hydrolysate; QA1a: $>10$ kDa; QA1b: 5-10 kDa; QA1c: 3-5 kDa; QA1d: $<3 \mathrm{kDa}$.

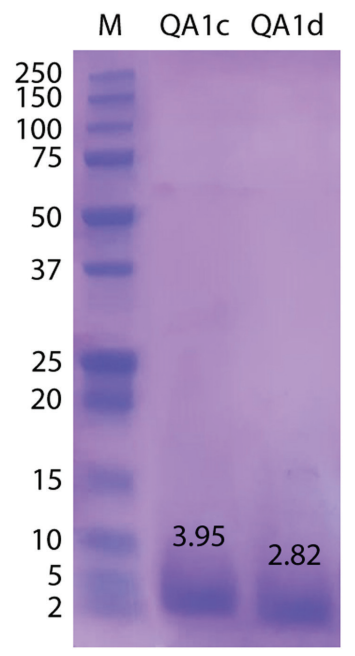

Figure 2. SDS PAGE chromatogram of protein hidrolysate QA1c (MW 3-5 $\mathrm{kDa})$ dan QA1d $(\mathrm{MW}<3 \mathrm{kDa})$ and $\mathrm{M}=$ Marker. 


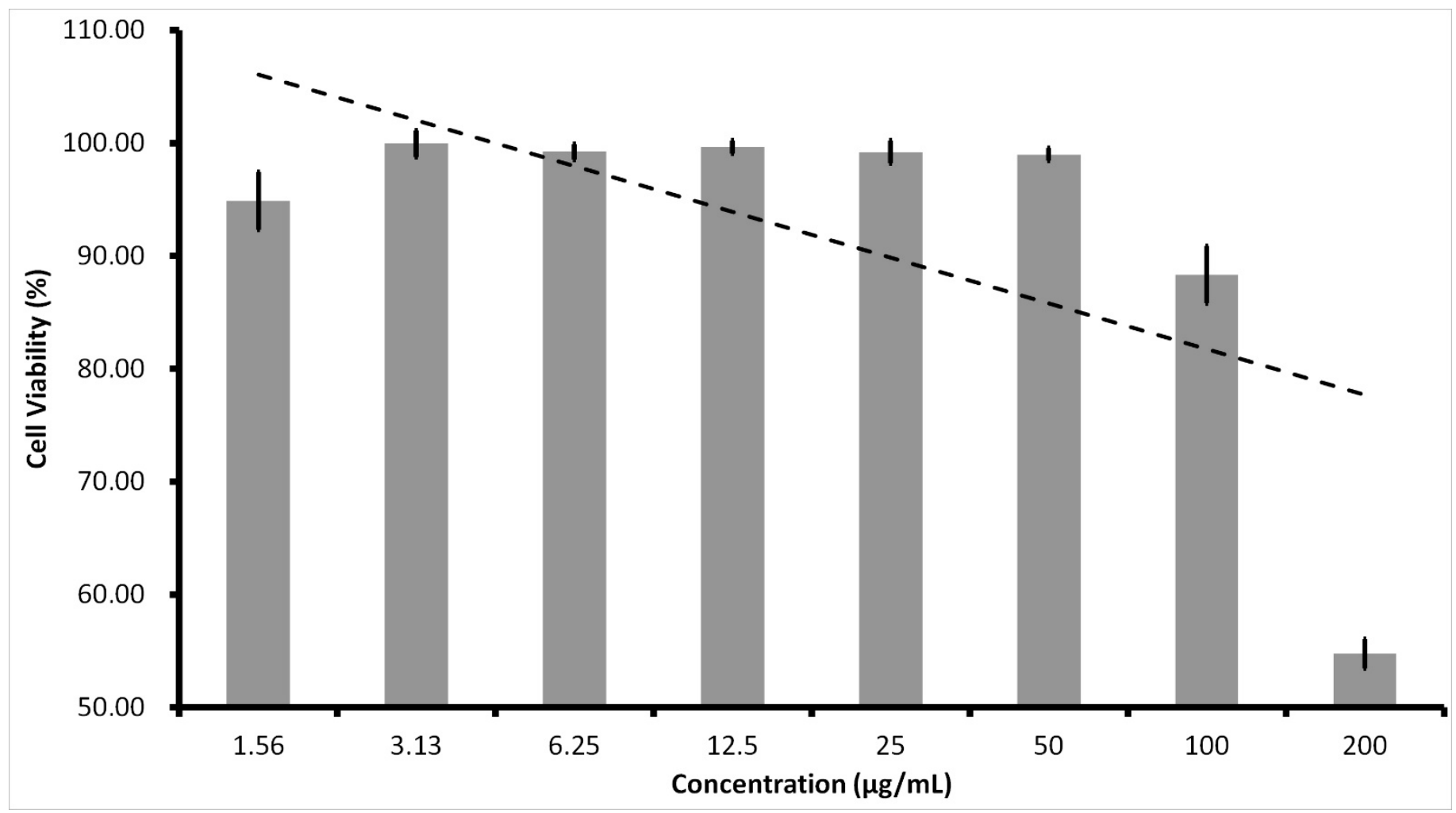

Figure 3. Relationship of QA1d peptide concentrations to the percentage of HeLa cell viability.

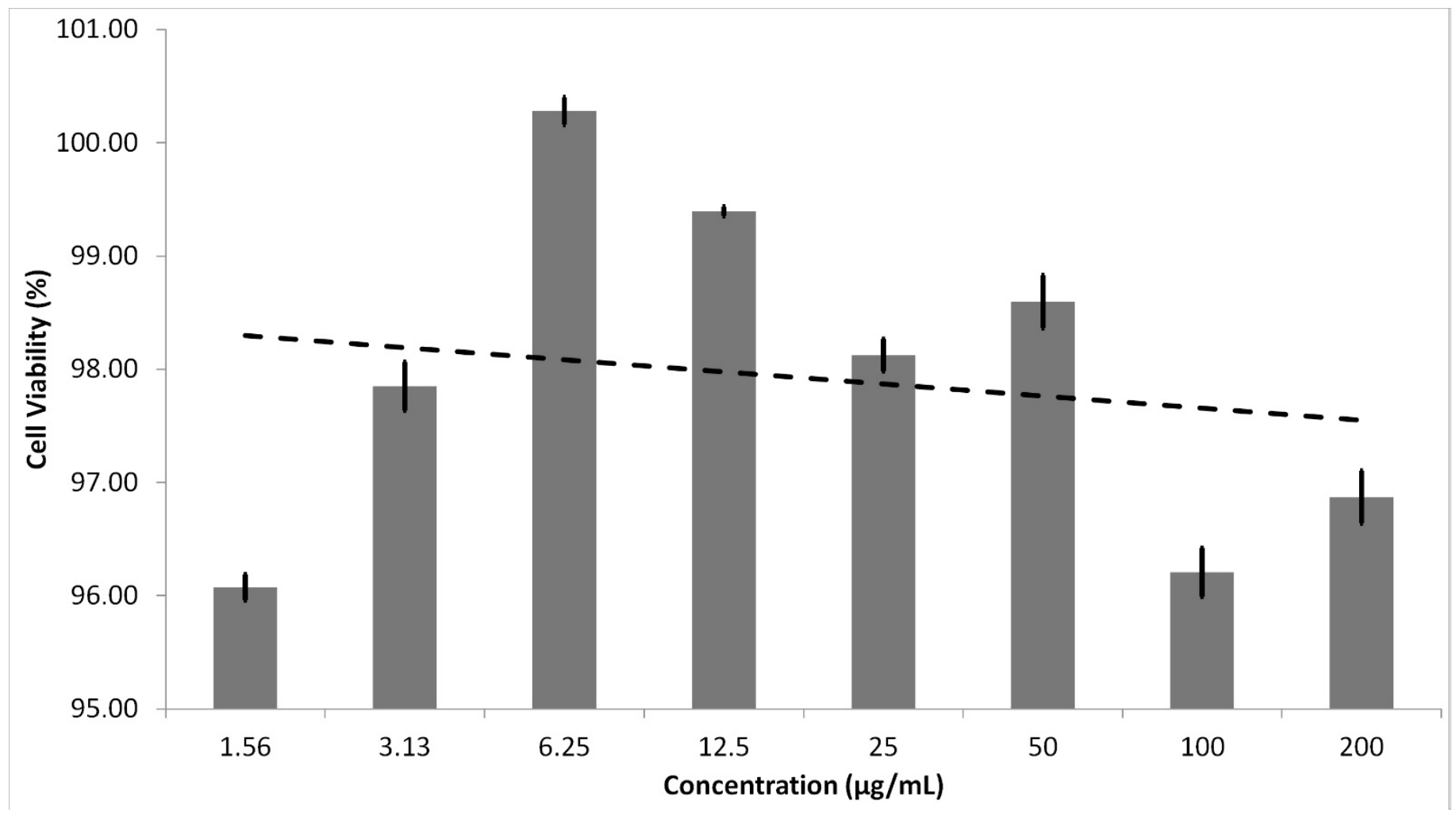

Figure 4. Relationship of QA1c peptide concentrations to the percentage of HeLa cell viability. 


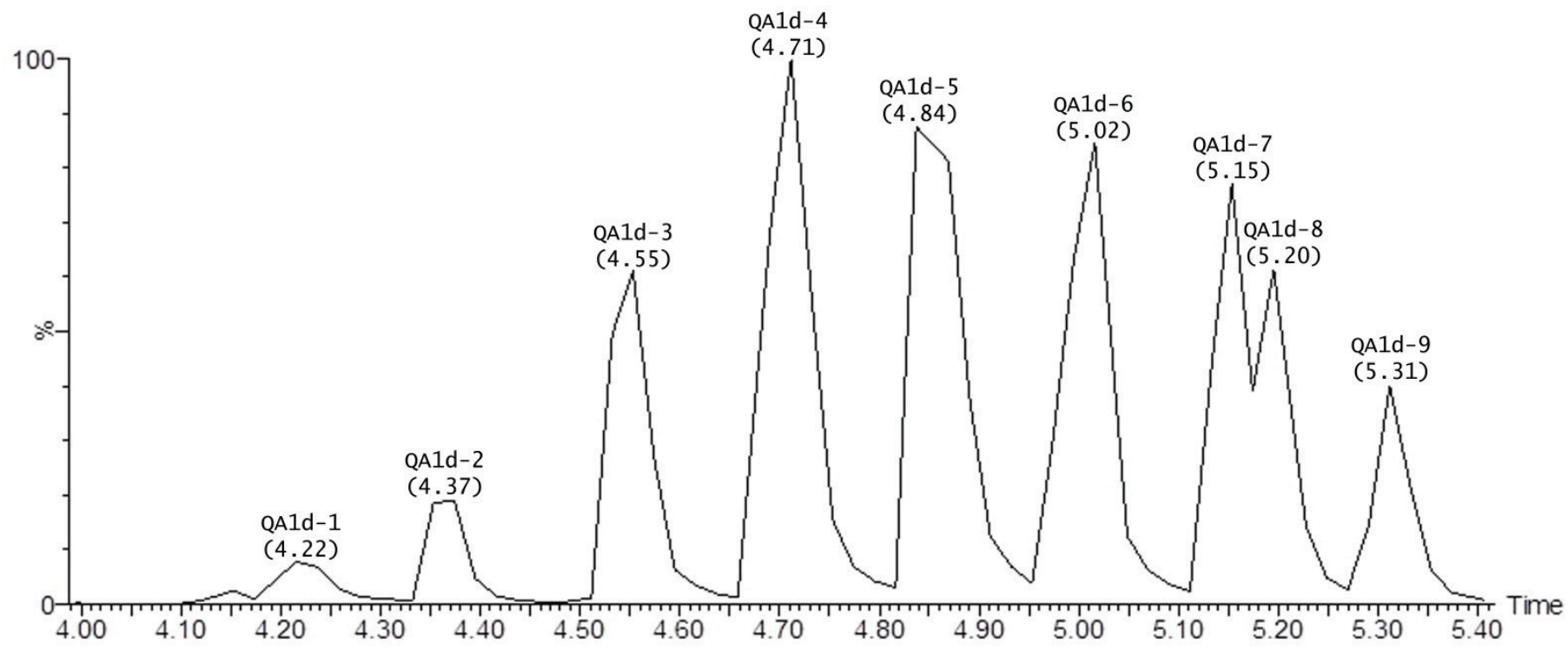

Figure 5. LC profile of protein hydrolysate QA1d.

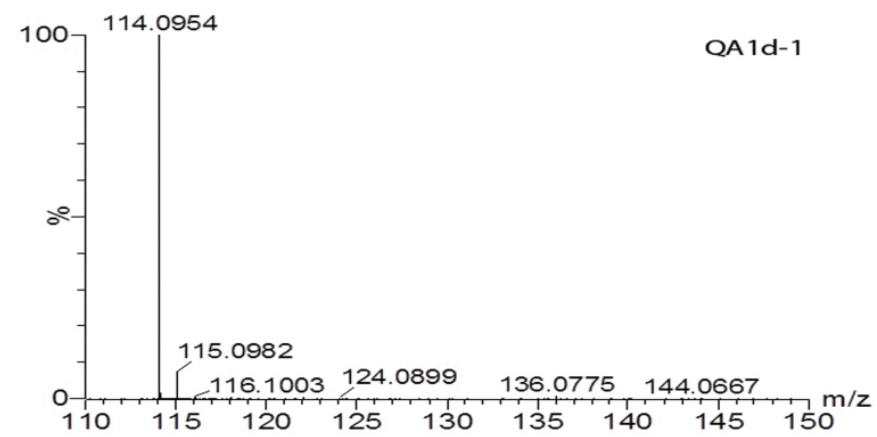

(a)

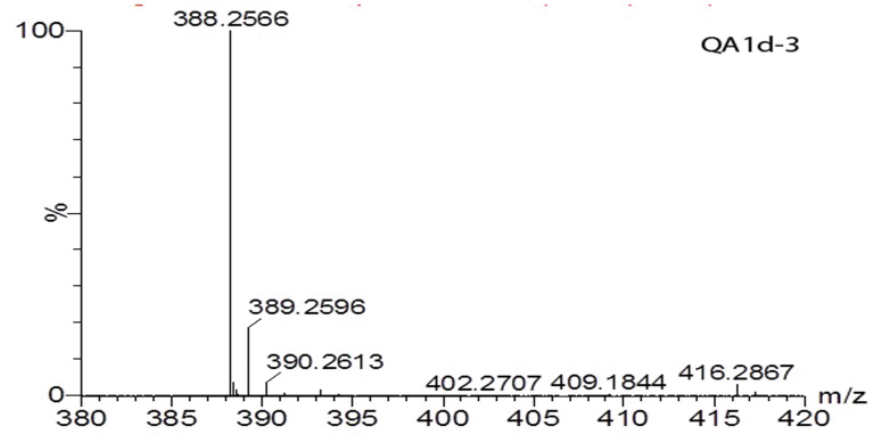

(c)

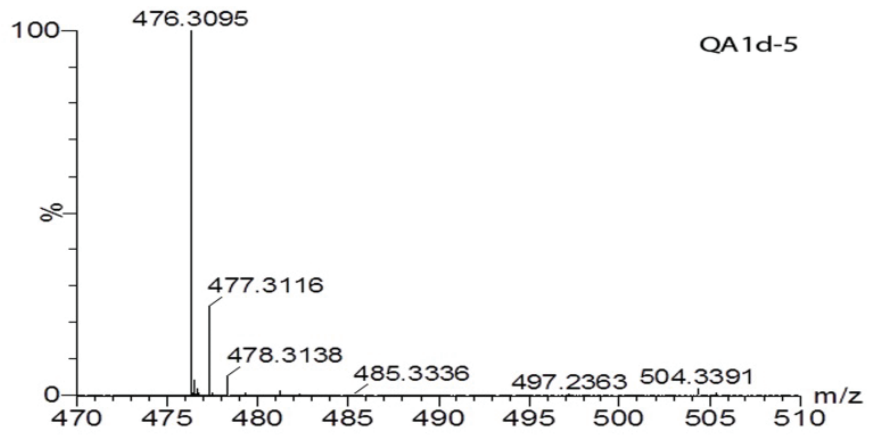

(e)

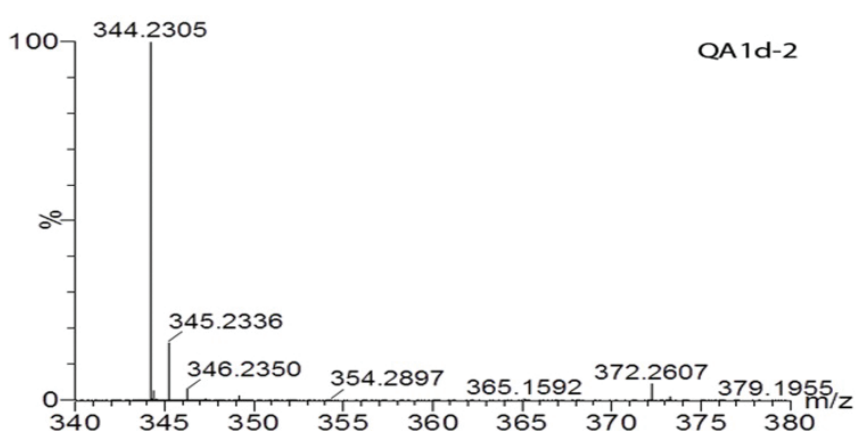

(b)

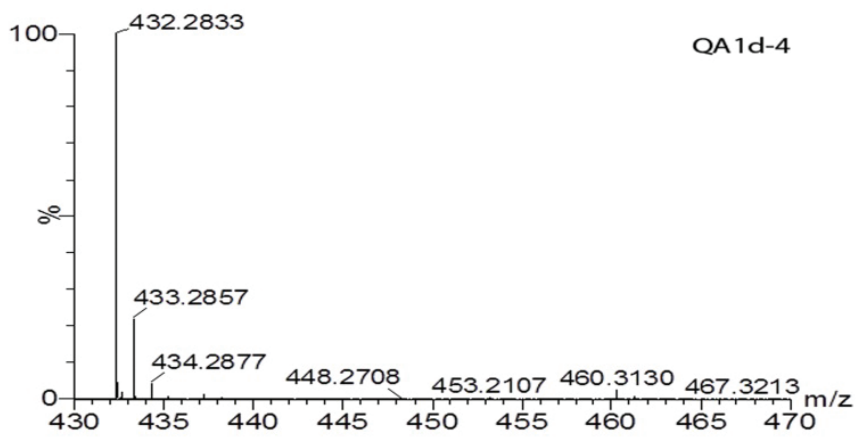

(d)

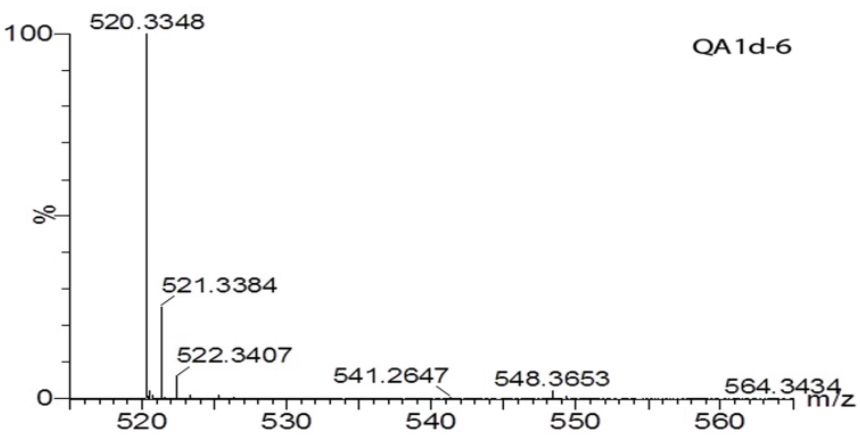

(f) 


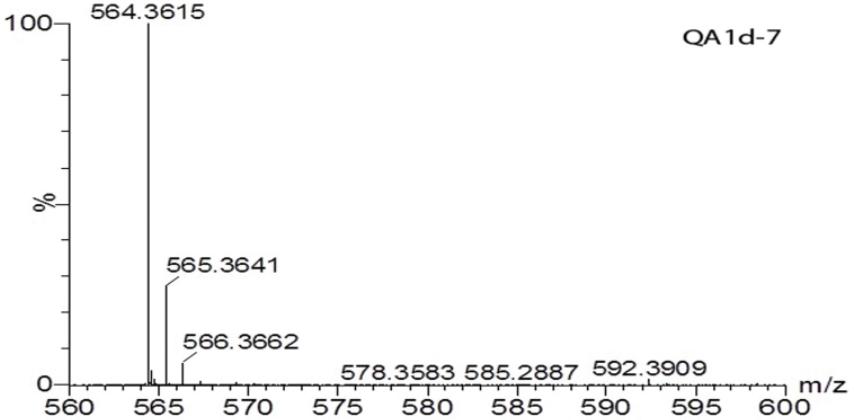

(g)

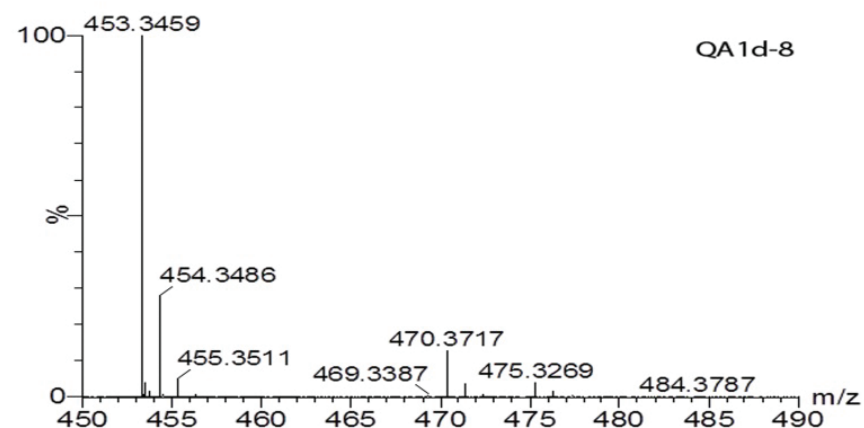

(h)

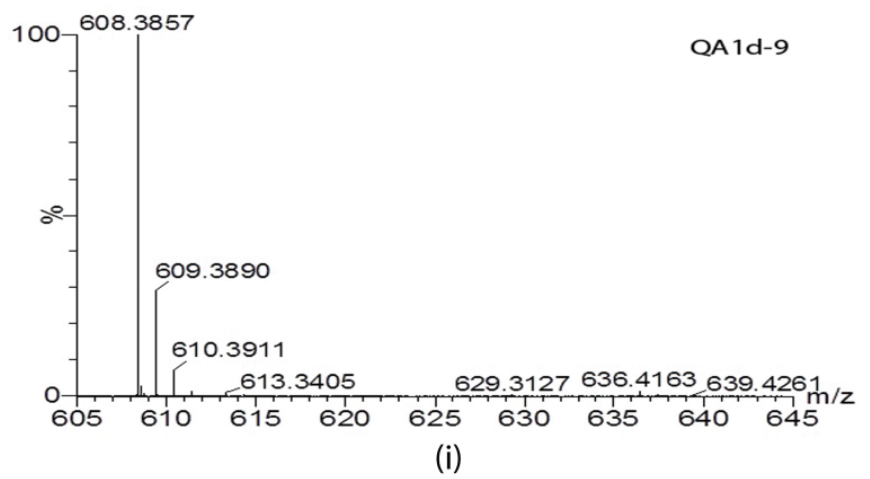

Figure 6. MS/MS spectra QA1d. (a) MS/MS spectra QA1d-1, (b) MS/MS spectra QA1d-2, (c) MS/MS spectra QA1d-3, (d) MS/MS spectra QA1d-4, (e) MS/MS spectra QA1d-5, (f) MS/MS spectra QA1d-6, (g) MS/MS spectra QA1d-7, (h) MS/MS spectra QA1d-8, and (i) MS/MS spectra QA1d-9.

Table 4. Identification of peptides by the MASCOT program.

\begin{tabular}{|c|c|c|c|c|c|c|c|c|}
\hline Code & Peptide sequence & MW (Da) & $\begin{array}{l}\text { Amino acid } \\
\text { amount }\end{array}$ & score & $\begin{array}{c}\text { Protein } \\
\text { coverage }(\%)\end{array}$ & $\begin{array}{l}\text { ID protein } \\
\text { (NCBIprot) }\end{array}$ & Original protein & Original organism \\
\hline QA1d-1 & FLP & 375.47 & 3 & 40 & 12 & KKT52525.1 & $\begin{array}{l}\text { Hypothetical protein } \\
\text { UW44_C0001G0077 }\end{array}$ & $\begin{array}{l}\text { Candidatus Collierbacteria } \\
\text { bacterium } G W 2011 \_ \\
\text {GWB2_44_22 }\end{array}$ \\
\hline QA1d-2 & MGFVLLQLLCFTVF & $1,631.07$ & 14 & 84 & 4 & XP_021659746.1 & $\begin{array}{l}\text { Non-classical } \\
\text { arabinogalactan } \\
\text { protein 31-like }\end{array}$ & Hevea brasiliensis \\
\hline QA1d-3 & MFLATLLSIGLMTFRIL & $1,940.48$ & 17 & 84 & 24 & WP_088762647.1 & hypothetical protein & $\begin{array}{l}\text { unclassified } \\
\text { Sphingobacteriales } \\
\text { (miscellaneous) }\end{array}$ \\
\hline QA1d-4 & HAILRGLLCLSLTLAFQPAF & $2,184.67$ & 20 & 103 & 4 & WP_136162937.1 & $\begin{array}{l}\text { M48 family } \\
\text { metalloprotease }\end{array}$ & Sphingomonas sp. ZLT-5 \\
\hline QA1d-5 & AFTFPLYPAFVVFLPGTVL & $2,099.54$ & 19 & 78 & 8 & XP_024692302.1 & $\begin{array}{l}\text { DUF775-domain- } \\
\text { containing protein }\end{array}$ & $\begin{array}{l}\text { Aspergillus campestris IBT } \\
28561\end{array}$ \\
\hline QA1d-6 & MNYLLLIKFKYTLSFQF & $2,169.65$ & 17 & 80 & 3 & PKP27261.1 & Cytochrome $\mathrm{C}$ & $\begin{array}{l}\text { Bacteroidetes bacterium } \\
H G W \text {-Bacteroidetes- } 22\end{array}$ \\
\hline QA1d-7 & DEASFFERLGLRRLFFMSSL & $2,421.80$ & 20 & 81 & 4 & WP_144233976.1 & Hypothetical protein & Desulfovibrio marinus \\
\hline QA1d-8 & ALHLPLKLMLRPALPLRLKLTL & $2,521.28$ & 22 & 86 & 4 & RXN20527.1 & $\begin{array}{l}\text { Tyrosine- phosphatase } \\
\text { 10D }\end{array}$ & Labeo rohita \\
\hline QA1d-9 & LTHELDQSFLSHNFMSIQFLQHVL & $2,885.29$ & 24 & 86 & 7 & XP_015878958.1 & $\begin{array}{l}\text { Protein } \\
\text { LOC107415185 }\end{array}$ & Ziziphus jujube \\
\hline
\end{tabular}

contact and the active peptides to be positively charged. Based on the physicochemical analysis, authors found that peptides (QA1d4 and QA1d-8) were positively charged, QA1d-4 peptides were $\delta$ +1.25 and QA1d-8 were $\delta+4.25$.
BLAST searches on NCBIprot and Uniprot show that both QA1d-4 and QA1d-8 peptides have never been reported, thus indicating that both peptides are newly discovered and are therefore promising antibacterial and anticancer agents in the future. 
Table 5. The antibacterial and anticancer activity prediction of peptide.

\begin{tabular}{llll}
\hline Code & Peptide sequence & Antibacterial prediction & Anticancer prediction \\
\hline QA1d-2 & MGFVLLQLLCFTVF & Non-AMP & Non-Anticp \\
QA1d-3 & MFLATLLSIGLMTFRIL & Non-AMP & Non-Anticp \\
QA1d-4 & HAILRGLLCLSLTLAFQPAF & AMP & Anticp \\
QA1d-5 & AFTFPLYPAFVVFLPGTVL & Non-AMP & Non-Anticp \\
QA1d-6 & MNYLLLIKFKYTLSFQF & Non-AMP & Non-Anticp \\
QA1d-7 & DEASFFERLGLRRLFFMSSL & Non-AMP & Non-Anticp \\
QA1d-8 & ALHLPLKLMLRPALPLRLKLTL & AMP & Anticp \\
QA1d-9 & LTHELDQSFLSHNFMSIQFLQHVL & Non-AMP & Non-Anticp \\
\hline
\end{tabular}

\section{CONCLUSION}

In this study, authors obtained a protein hydrolysate QA1d $(<3 \mathrm{kDa})$ from Vibrio $s p$. ES25 which actively inhibited the growth of $S$. aureus at $13.26 \pm 0.65 \mathrm{~mm}$, was very toxic to Artemia salina with $\mathrm{LC}_{50}$ values $1.03 \mu \mathrm{g} / \mathrm{ml}$ and proliferation of HeLa cancer cells with $\mathrm{IC}_{50}$ values $248.18 \mu \mathrm{g} / \mathrm{ml}$, considered to moderate. Then two novel peptides were then identified from QA1d and predicted to be the source of this bioactivity: QA1d-4 (HAILRGLLCLSLTLAFQPAF) and QA1d-8 (ALHLPLKLMLRPALPLRLKLTL). These could prove to be good candidates for novel drug production in the future.

\section{ACKNOWLEDGMENT}

The author thanks The Endowment Fund for Education (LPDP) Ministry Finance of Indonesia has supported this research (Contract number: PRJ-5155/LPDP.3/2016) by the scheme flagship scholarship for Indonesian domestic lecturers (BUDIDN). The authors also thank Sicesa Scienta for writing assistance.

\section{AUTHOR'S CONTRIBUTION}

Data gathering and idea owner of this study: Sugrani A., Ahmad A., Djide M. N., Natsir H.

Study design: Sugrani A., Ahmad A., Djide M. N.

Data collection: Sugrani A., Natsir H.

Manuscript writing: Sugrani A., Ahmad A.

Editing of final manuscript: Sugrani A., Ahmad A., Djide M. N., Natsir H.

\section{CONFLICT OF INTEREST}

Authors declared that there is no conflicts of interest.

\section{REFERENCES}

Akone SH, Daletos G, Lin W, Proksch P. Unguisin F, a new cyclic peptide from the endophytic fungus Mucor irregularis. Z Naturforsch C J Biosci, 2016; 71(1-2):15-9; doi:10.1515/znc-2015-0137

Chu HL, Yip BS, Chen KH, Yu HY, Chih YH, Cheng HT, Chou YT, Cheng JW. Novel antimicrobial peptides with high anticancer activity and selectivity. PLoS One, 2015; 10(5):1-14; doi:10.1371/journal. pone. 0126390

Cullen TW, Schofield WB, Barry NA, Putnam EE, Rundell EA, Trent MS, Degnan PH, Booth CJ, Yu H, Goodman AL. Antimicrobial peptide resistance mediates resilience of prominent gut commensals during inflammation. Science, 2015; 347(6218):170-5; doi:10.1126/ science. 1260580

Gasteiger E, Hoogland C, Gattiker A, Wilkins MR, Appel RD, Bairoch A. Protein identification and analysis tools on the ExPASy server. In: Walker JM (ed.). The proteomics protocols handbook. Humana Press, Totowa, NJ, pp 571-607, 2005; doi:10.1385/1-59259-890-0:571
Guo P, Qi Y, Zhu C, Wang Q. Purification and identification of antioxidant peptides from Chinese cherry (Prunus pseudocerasus Lindl.) seeds. J Funct Foods, 2015; 19:394-403; doi:10.1016/j.jff.2015.09.003

Hailu HW, Abdallah V, Susilowati A, Raqib SM, ALatawi ARA. Biochemical characterization, 16S rRNA sequence analysis and multiple sequence alignment of bacteria isolated from fermented and unfermented coconut. Biotechnol J Int, 2015; 5(1):51-61; doi:10.9734/BBJ/2015/14523

Ibrahim MA, El Nur EE. Cytotoxicity study on Maerua pseudopetalosa (Glig and Bened.) De Wolf tuber fractions. Afr J Plant Sci, 2015; 9(12):490-7; doi:10.5897/AJPS2015.1333

Jung HJ, Kim Y, Lee HB, Kwon HJ. Antiangiogenic activity of the lipophilic antimicrobial peptides from an endophytic bacterial strain isolated from red pepper leaf. Mol Cells, 2015; 38(3):273-8; doi:10.14348/ molcells.2015.2320

Kadam SU, Tiwari BK, Álvarez C, O'Donnell CP. Ultrasound applications for the extraction, identification and delivery of food proteins and bioactive peptides. Trends Food Sci Technol, 2015; 46(1):60-7; doi:10.1016/j.tifs.2015.07.012

Kakade PD, Chaphalkar SR. Isolation and purification of antibacterial peptide from Bacillus safensis, endophytica bacteria from Anthocephalus kadamba. Int J Curr Microbiol App Sci, 2017; 6(1):504-11; doi:10.20546/ijcmas.2017.601.060

Lee SY, Hur SJ. Purification of novel angiotensin converting enzyme inhibitory peptides from beef myofibrillar proteins and analysis of their effect in spontaneously hypertensive rat model. Biomed Pharmacother, 2019; 116:109046; doi:10.1016/j.biopha.2019.109046

Li S, Dong S, Xu W, Tu S, Yan L, Zhao C, Ding J, Chen X. Antibacterial Hydrogels. Adv Sci, 2018; 5(5):1700527; doi:10.1002/ advs.201700527

Maehre HK, Dalheim L, Edvinsen GK, Elvevoll EO, Jensen IJ. Protein determination method matters. Foods, 2018; 7(1):5; doi:10.3390/ foods 7010005

Mansfield MJ, Adams JB, Doxey AC. Botulinum neurotoxin homologs in non-Clostridium species. FEBS lett, 2015; 589(3):342-8; doi:10.1016/j.febslet.2014.12.018

Naimah AK, Al-Manhel AJA, Al-Shawi MJ. Isolation, purification and characterization of antimicrobial peptides produced from Saccharomyces boulardii. Int J Pept Res Ther, 2018; 24(3):455-61; doi:10.1007/s10989-017-9632-2

Singh B, Kaur A. Antidiabetic potential of a peptide isolated from an endophytic Aspergillus awamori. J Appl Microbiol, 2016; 120(2):30111; doi:10.1111/jam.12998

Stan GS, Badea IA, Aboul-Enein HY. HPLC method for quantification of five compounds in a parenteral form used in treatment of companion animals. J Chromatogr Sci, 2016; 54(9):1567-72; doi:10.1093/ chromsci/bmw105

Sucher NJ. Searching for synergy in silico, in vitro, and in vivo. Synergy, 2014; 1(1):30-43; doi:10.1016/j.synres.2014.07.004

Sugrani A, Ahmad A, Djide MN, Natsir H. Antibacterial and anticancer activity of protein sponges collected from the waters of Kapoposang Island of south Sulawesi, Indonesia. Int Res J Pharm, 2019a; 10(1):82-7; doi:10.7897/2230-8407.100115 
Sugrani A, Ahmad A, Djide MN, Natsir H. Toxicological evaluation and antibacterial activity of crude protein extract from endophytic bacteria associated with Algae Eucheuma spinosum. J Phys Conf Ser 2019b; 1341(3):1-11. (Invited speaker of 3th International Conference of Sciences); doi:10.1088/1742-6596/1341/3/032006

Tyagi A, Kapoor P, Kumar R, Chaudhary K, Gautam A, Raghava GPS. In silico models for designing and discovering novel anticancer peptides. Sci Rep, 2013; 2984(3):1-7; doi:10.1038/srep02984

Tyagi A, Tuknait A, Anand P, Gupta S, Sharma M, Mathur D, Joshi A, Singh S, Gautam A, Raghava GP. CancerPPD: a database of anticancer peptides and proteins. Nucleic Acids Res, 2015; 43(D1):D837-43; doi:10.1093/nar/gku892

Waghu FH, Barai RS, Gurung P, Idicula-Thomas S. CAMPR3: a database on sequences, structures and signatures of antimicrobial peptides. Nucleic Acids Res, 2016; 44(D1):D1094-7; doi:10.1093/nar/gkv1051

Wang L, Dong C, Li X, Han W, Su X. Anticancer potential of bioactive peptides from animal sources. Oncol Rep, 2017; 38(2):637-51; doi:10.3892/or.2017.5778
Wang Z, Zhang X. Isolation and identification of antiproliferative peptides from Spirulina platensis using three-step hydrolysis. J Sci Food Agric, 2016; 97(3):918-22; doi:10.1002/jsfa.7815

Weerapreeyakul N, Nonpunya A, Barusrux S, Thitimetharoch T, Sripanidkulchai B. Evaluation of the anticancer potential of six herbs against a hepatoma cell line. Chin Med, 2012; 7(15):1-7; doi:10.1186/17498546-7-15

How to cite this article:

Sugrani A, Ahmad A, Djide MN, Natsir H. Two novel antimicrobial and anticancer peptides prediction from Vibrio $s p$. strain ES25. J Appl Pharm Sci, 2020; 10(08):058-066. 